\title{
Biotechnology, Crop R\&D and Public Policy: The Case of Canola
}

\author{
By Stavroula Malla* \& Derek G. Brewin ${ }^{\dagger}$
}

\begin{abstract}
The importance of IPRs (Intellectual Property Rights) in enhancing investment in research related to crop biotechnology is explored through an updated review of the evidence related to canola in Canada. Relevant past work on the rise of private investment in canola is examined and recent updates are presented. The case for continued public investment in crop research even for a crop with significant IPR protection is discussed theoretically and recent and past evidence related to this theory is explored. The benefit of the biotechnology applied to canola to farmers, to plant breeders, to the health of Canadians and to the environment are examined and confirmed. (JEL H00, L00, Q00, Q16, Q18)
\end{abstract}

Keywords: Biotechnology, Canola, Intellectual Property Rights, Public Policies, $R \& D$.

\section{Introduction}

With the advance in biotechnology, crop research around the word has undergone a major transformation. This is especially true in North America were private incentives to invest in plant breeding have dramatically changed. In the 1970s, most R\&D (Research \& Development) was publicly funded (Huffman and Evenson 1993, Malla and Brewin 2015, 2019). The private sector had underinvested from a social point of view. Government intervention was justified primarily on the basis that research outcomes were non-excludable in nature (meaning the inventor did not have the ability to exclude others from using, reproducing, and selling the new technology or product created from the R\&D). This created limited private $R \& D$ incentives. Hence, governments intervened to correct the market failure. Other reasons for government involvement were: poor or non-enforceable property rights; many small producers (free rider); and externalities associated with the use of the technology. These theoretical arguments have been supported with many empirical studies and evidence that have estimated high rates of returns to agricultural research. Below we list a number of studies found a very high social rate of return to agricultural research often $30-50 \%$ or greater and supporting evidence of a problem with private investment and a justification for government involvement in R\&D.

The introduction of biotechnology and IPRs (Intellectual Property Rights) has specifically transformed the Canadian canola industry (Malla and Gray 2003, 2005). Canola has changed from a minor crop to the dominant revenue earning

*Associate Professor, University of Lethbridge, Canada.

${ }^{\dagger}$ Associate Professor, University of Manitoba, Canada. 
crop in western Canada; as well, the canola industry has experienced significant growth. The area seeded to canola varieties $\&$ the number of varieties available has been dramatically increasing overtime. The area seeded to canola has increased from less than $1 \%$ of crop land in western Canada in the early 1960 s to $32 \%$ of seeded area in 2018 (Statistics Canada n.d).

Government research policies have changed as the structure of the canola research industry changed. Consequently, the question that arises is whether today's government involvement in canola R\&D is appropriate or sufficient. There is concern that the growth in the canola sector can be sustained over time. Given all the changes in the canola sector, another issue is whether producers benefit from the new biotechnologies.

The objective of this paper is to provide an updated overview and critical assessment of the biotech canola industry in Canada and to evaluate the impact of biotechnology over time. The study will also review the change in research policies in Canada over time and examine the appropriate roles for government.

\section{Impacts of Biotechnology in the Canola Sector: Overview \& Assessment}

\section{Rapeseed to "Canola"}

In Canada, the public sector became involved in rapeseed research shortly after World War II as a result of shortages of edible oils (Gray and Malla 2001, Gray et al. 2006). In response to the increasing demand for edible oil, Agriculture Canada engaged in research for new processing techniques and agronomic improvements of rapeseed (canola) varieties during the 1940s and 1950s (Gray and Malla 2001). By the 1950s, rapeseed was being produced for commercial sale until 1956 when it was determined that the high levels of erucic acid and glucosinolate in rapeseed posed significant health risks. As a result, breeders began attempting to develop varieties with low levels of erucic acid (Gray and Malla 2001).

The early days of the canola industry were characterized by a lack of welldefined intellectual property rights and, as a result, there was little investment from private firms as they were unable to capture a return on rapeseed research and research was conducted almost entirely in the public realm. In 1967, the Rapeseed Association of Canada (Canola Council after 1980) was formed as a non-profit organization with $70 \%$ of its funding obtained from taxes paid by the industry and $30 \%$ from government sources (Gray et al. 2006). The Rapeseed Association of Canada did not conduct its own research but instead coordinated research and development efforts across the industry and provided funding to external research projects. During the initial stages of canola research, funding was provided to public institutions that focused mainly on developing new varieties of canola that were more suited to human consumption. In 1974, the first Argentine-type (Brassica napus) rapeseed variety with zero erucic acid and low-gluconate (called Tower) was released, while in 1977 the first Polish-type (Brassica rapa) variety with zero erucic acid and low-gluconate (called Candle) was registered. Further, in 
1978 the name "canola" ${ }^{1}$ " was created for marketing rapeseed varieties with lowerucic acid and low-gluconate levels (Gray et al. 2006).

During the early 1980s, the public sector engaged in research on plant breeding techniques and hybridization (Gray and Malla 2001). Hybrid seeds are a cross between parent with significantly different genetic lines that result in hybrid vigor result and a large increase in the yield of a crop (Brewin and Malla 2014). Another very important characteristic of hybrids is that the reproduction of the crop during successive plantings of the initial seed does not produce a lower yield than the initial seeding. As a result, producers need to repurchase the crop each year in order to receive the benefits of an increased yield. The development of hybrids created a biological form of property rights and attracted many private firms to enter the industry and engage in canola plant breeding. In addition to the development of hybrids, the introduction of the Canadian Plant Breeders' Rights Act in 1990 and the ability to patent living organisms allowed private firms to capture a return on research investments and as a result there was a large influx of private firms developing new canola varieties and biotechnologies (Carew 2000).

\section{Overview of Changes: Biotechnology \& IPRs}

The IPRs for all crop research in Canada have been advancing over time. Prior to the late 1980s all canola varieties were open-pollinated and no effective Plant Breeder's Rights (PBR) were established, as well as the farmers had the right to retain production for future seed use. This situation changed during the late 1980s and through the 1990s. In the late 1980s some versions of PBR were passed (Brewin and Malla 2014). At the same time patenting of biological traits developed through biotechnology were allowed (Carew 2000). This led to the introduction for technology use agreements that enable research firms to charge farmers an annual fee for growing their varieties. During the same period some of the new varieties become excludable via genetic traits. Hybrid varieties required the purchase of the seed every year to retain the desirable traits, and herbicide-tolerant (HT) varieties, linked to specific herbicides, contained designer traits varieties that could control the retention of seeds and thus subsequent farmer use.

The industry often has license agreements for patented products; some of the laws allow for the exclusions of others from using the technology without paying fees. By 2000, about $80 \%$ of the canola acreage was seeded to HT varieties. By $2010,85 \%$ of the seeded area of canola was hybrid varieties and over $90 \%$ were HT varieties (Malla and Brewin 2015).

The introduction of biotechnology and IPRs has altered the nature of research products from being non-excludable to excludable goods. This creates incentives for private investment because the inventor can extract most of the economic rents from their investment by retaining ownership over the new technology. Hence, firms went from no ability to capture value to holding property rights that allow them to charge farmers each year for the right to grow their varieties. Consequently,

\footnotetext{
"Canola" is not the term commonly used for this type of rapeseed in Europe. "Double Low" Oilseed Rape is the most specific term for a comparable Rapeseed variety in the EU (German Seed Alliance n.d.).
} 
there was an increase in private $R \& D$ investment, and a change in the nature of the agricultural R\&D industry (i.e., the non-rival nature of research output $\&$ freedom to operate concerns has leaded to a concentrated industry). In the 1970 s, $\$ 18$ million was spent on public research into canola; $83 \%$ of the total spent. By 1980 , research investment was $69 \%$ public versus $31 \%$ private; and by 1999 , the private sector's share had grown to $70 \%$ (of a total $\$ 149$ million expenditure) (Gray et al. 2001, Malla and Gray 2005).

Private firms also control most of the research output, in terms of the registration of new varieties and proprietary technology; and have started capturing private market share and revenue due to their R\&D investment. By 2001, private canola breeding firms collecting over $\$ 250$ million in revenue (Gray et al. 2001, Malla and Gray 2005). The $90 \%$ HT shares noted above show, where virtually all private seeds, leading to a nearly complete crowding out of public varieties.

\section{Important Trends in Canada's Canola Crop: Area Seeded Overtime}

Overall the area seeded to canola varieties has significantly increased overtime with the introduction of biotechnology and improved IPRs. Figure 1 shows the area of rapeseed/canola seeded in Canada overtime, which depicts three important increases in area. Specifically, the first significant area increase took place around 1970 with the introduction of 'canola' varieties. The second increase took place around 1996, as a result of private breeders entering the canola market with herbicide tolerant (HT) and hybrids varieties. The third shift started around 2004 because of the introduction of very high yielding hybrid varieties especially Bayer's Invigor products.

Figure 1. Canola Area Seeded in Canada

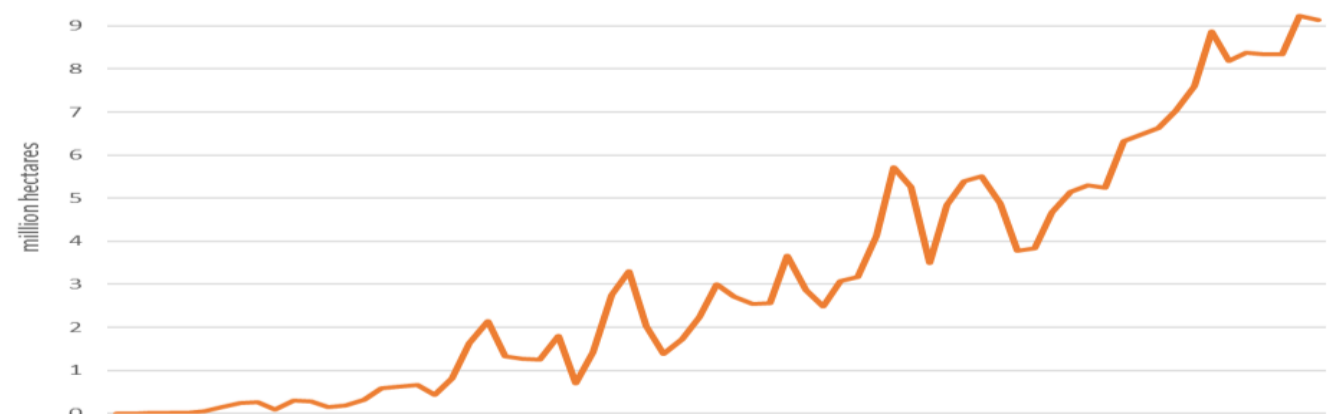

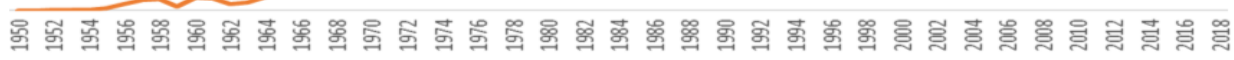
Source: Statistics Canada n.d.

\section{Benefits of New Biotechnologies}

Returns to Research, Environmental \& Health Benefits

Investment in agricultural $R \& D$ results in high rates of returns in general (e.g., Alston et al. 1998, Brinkman 2004, Gray and Malla 2007, Klumper and Qaim 2014). In particular, many studies have found high returns and significant producer 
benefits to canola research investment (e.g., Nagy and Furtan 1978, Ulrich et al. 1984, Ulrich and Furtan 1985).

The introduction of biotechnology has resulted in significant economic benefits in the canola sector (e.g., Malla et al. 2004, Phillips 2003, Brewin and Malla 2012, Malla and Brewin 2015). It has also been shown that there are substantial indirect environmental benefits associated with agronomic improvement and technical change in the canola sector; for example: better weed management, reduce tillage, reduce herbicide, and a reduction in carbon release (Smyth et al. 2010, Gusta et al. 2011, Smyth et al. 2011a,b). Further, there are nontrivial direct and indirect health benefits associated with quality improving technical change; for example health cost savings from a reduction in daily transfat intake related to Nexera canola; and the switch from rapeseed to canola (Gray and Malla 2001, Malla et al. 2007).

Lastly, Klumper and Qaim (2014) conducted a meta-analysis on genetically modified crops and concluded that "On average, GM technology adoption has reduced chemical pesticide use by $37 \%$, increased crop yields by $22 \%$, and increased farmer profits by $68 \%$. Yield gains and pesticide reductions are larger for insect-resistant crops than for herbicide-tolerant crops" (Klumper and Qaim 2014: 1). While, EASAC (2013) concluded that "There is no validated evidence that GM crops have greater adverse impact on health and the environment than any other technology used in plant breeding. There is compelling evidence that GM crops can contribute to sustainable development goals with benefits to farmers, consumers, the environment and the economy...the potential benefits of crop genetic improvement technologies are very significant. Capturing these benefits in agricultural innovation should be a matter for urgent attention by EU policymakers, alongside the development of indicators to monitor success in attaining the objectives (for example, for efficient and diversified land use)." (Klumper and Qaim 2014: 2)

Assessing Producers' Benefits

The returns to Canadian producers have been high from the adoption of HT canola seeding systems. Specifically, recent yield gains and herbicide cost savings associated with the new and competing HT platforms have led to significant gains to canola producers. 
Table 1. Returns to Canadian Canola Farmers: HT Average benefits (2016)

\begin{tabular}{|c|c|c|c|c|}
\hline Farmer System Costs & Non-HT & $\begin{array}{c}\text { Liberty } \\
\text { Link }\end{array}$ & $\begin{array}{l}\text { Clear- } \\
\text { Field }\end{array}$ & $\begin{array}{c}\text { Roundup } \\
\text { Ready }\end{array}$ \\
\hline Seed Cost (\$/ha) & $\$ 49$ & $\$ 122$ & $\$ 118$ & $\$ 111$ \\
\hline Herbicide Cost (\$/ha) & $\$ 74$ & $\$ 29$ & $\$ 34$ & $\$ 12$ \\
\hline TUA (\$/ha) & $\$ 0$ & $\$ 26$ & $\$ 30$ & $\$ 37$ \\
\hline System Cost (\$/ha) & $\$ 123$ & $\$ 177$ & $\$ 182$ & $\$ 160$ \\
\hline Yield (tne/ha) & 2.06 & 2.50 & 2.07 & 2.29 \\
\hline Commodity Price $(\$ / \mathrm{tn})$ & $\$ 480$ & $\$ 480$ & $\$ 480$ & $\$ 480$ \\
\hline Expected Gross Returns (\$/ha) & $\$ 989$ & $\$ 1,200$ & $\$ 994$ & $\$ 1,099$ \\
\hline Less System Costs $(\$ / \mathrm{ha})$ & $(\$ 123)$ & $(\$ 177)$ & $(\$ 182)$ & $(\$ 160)$ \\
\hline Net Farm Returns (\$/ha) & $\$ 866$ & $\$ 1,023$ & $\$ 812$ & $\$ 939$ \\
\hline
\end{tabular}

Sources: Seed Manitoba (various years), Manitoba Agricultural Services Corporation (n.d.), SaskSeed Guide (Various years), Agriculture Financial Services Corporation (various years), Alberta Seed Guide (various years), Statistics Canada (n.d.), Gray et al. (2006), Manitoba Agriculture, Food and Rural Initiatives (2011), Saskatchewan Ministry of Agriculture (2011), Malla and Brewin (2015), Saskatchewan Crop Insurance Corporation (SCIC) (2017) and authors' calculations.

Table 1 shows the direct net farm returns to each major HT system platform being used (Roundup Ready; Liberty Link; and Clearfield) in 2016. Comparing HT to non-HT varieties, the direct seed cost of HT and hybrid varieties is higher plus there is a cost for a technical use agreements (TUA) for HT varieties to capture some of the patent rents. The herbicide cost, however, is lower due to improved methods of weed control from HT. The total farmer system cost is overall higher with HT varieties, but yield levels are higher than those with non-HT varieties. There are significant yield gains attributed to hybridization facilitated by biotechnology. Thus, Canadian canola farmers can benefit from growing HT canola varieties over non-HT varieties. The estimated net farm returns were equal to: $\$ 1,023 /$ ha for the Liberty Link platform; $\$ 812 /$ ha for Clearfield; and $\$ 939 /$ ha for Roundup Ready in 2016. Compared to the non-HT returns this represents a gain of $\$ 157,(-\$ 54)$ and $\$ 73 /$ ha from these three hybrid HT systems. And these farmer benefits ignore other indirect benefits like positive externalities like reduced herbicide use.

\section{R\&D Policies, Regulations, and Government Role}

\section{Private Sector R\&D Underinvestment}

When firms invest in research, some of the benefits spillover to farmers: producers capture some benefits from the research the $R \& D$ firms are doing. Increasing profits is part of the demand for the research outputs like improved seeds. If the R\&D firm making the investment in research cannot capture enough of the increase in surplus going to the buyers of the products (farmers), the private 
marginal benefits from research are less than the social marginal benefits. As a result $R \& D$ firms invest less than the social optimum.

Figure 2. Socially Optimal vs Imperfectly Competitive $R \& D$

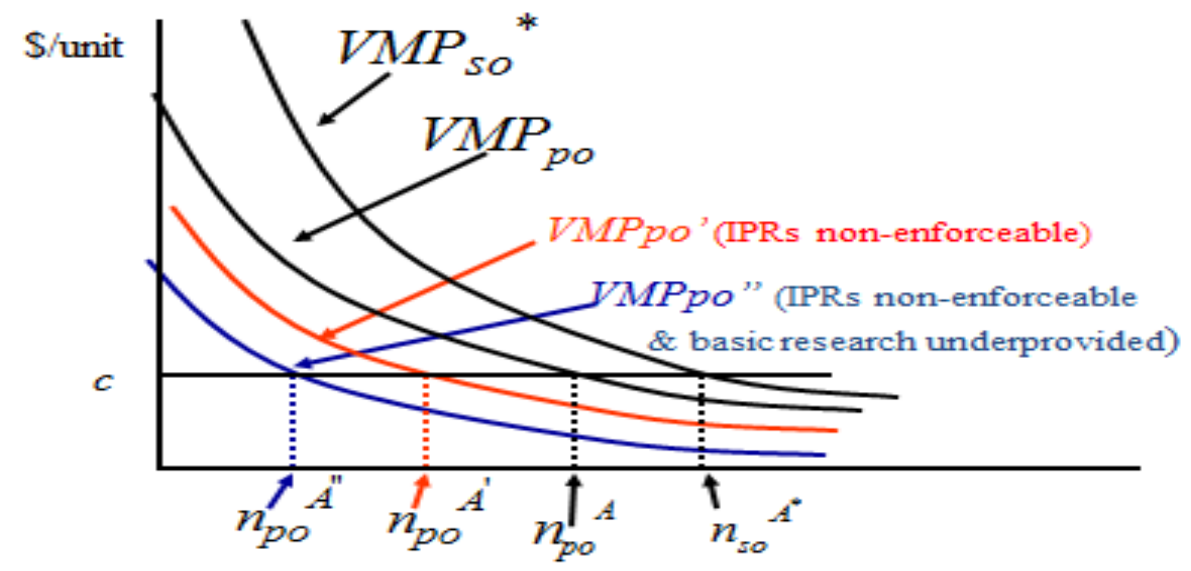

Source: Authors.

In Figure 2, the upper dark line is the social value of the marginal product (VMP) which includes the R\&D firms' profits and farmers' producer surplus (or benefits) as the R\&D expenditure increases. The private VMP, the lower dark line, is the value the $R \& D$ firms can capture in the market place. Given a fixed cost of $\mathrm{R} \& \mathrm{D}$, private firms alone will invest less than the social optimal amount. A private research firm will equate the marginal cost of doing research with the private demand (or private VMP) for research, and produce the private optimal quantity of research. The situation will get worse if there are incomplete (or not enforceable) IPRs which lower the amount the firm can capture even further, and pivot the VMP downwards, which results in lower research. Finally, if these market failures are combined with underinvestment in basic research, meaning that firms do not have the right technology to innovate with, the VMP falls further which in turn reduces even further the private optimal amount of research.

In short, private firms R\&D underinvest due to the firms' inability to capture all the benefits generated from R\&D; the situation is exaggerated when IPRs are non-enforceable; and even more when IPRs non-enforceable \& basic research is underprovided. This theoretical argument has been shown in the literature (Malla and Gray 2005). It supports the case that there is often private research underinvestment even with complete IPRs.

A Decrease in the Marginal Cost of Research Could Increase the Private Firm's $R \& D$

In Canada there are examples of government financial assistance for R\&D in the form of grants, infrastructure, matching funds. In the case that the government subsidizes the R\&D cost of private firms, the revenue for each firm is the same as before except the private cost of research is lower. Firms may capture the full value of their investment. Hence, a government subsidy that reduces the firms' per 
unit cost of research could increase the private provision of $R \& D$ towards the social optimum (Malla and Gray 2003). The potential problem associated with the subsidy is that it could lead to private sector over investment. It was also noted in the literature that in a case of almost complete IPRs coupled with government subsidization of research expenditure, the amount of private research could exceed the social optimal amount, leading to reduced returns to research, i.e. declining internal returns overtime (see Malla et al. 2004).

\section{An Increase in the Output Price Could Increase the Private Firm's $R \& D$}

Another way to subsidize R\&D is to lower the price paid by producers that to reflect the marginal cost of research. For example, governments could subsidize the output of research by providing farmers a subsidy to purchase new varieties. This could increase the price $R \& D$ firms received and pivot the private VMP closer to the social VMP and increase the private investment. The appropriate amount of subsidy could result in the private VMP to coincide with the social VMP, which could eliminate the underinvestment (Malla and Gray 2003).

\section{An Increase in Public Applied Research Could Reduce Private R\&D}

Public sector applied research reduces or crowds out the private sector investment in applied research. In the case that the public sector is directly involved in competing goods, in other words undertaking applied research, then the private firms' $R \& D$ incentive would be even further reduced, which could lead to even less private research. Assuming one firm is private, and one is public. A fully funded public firm would choose the optimal level of research investment. The public firm directly invests in applied research. For example, higher yields in a public variety reduces the demand for the private varieties; a downward shift of the VMP of the private research firm. The private firm responds to this reduced demand by further restricting the already limited research effort (is crowded out). Consequently, public applied research is a substitute to applied private research (Malla and Gray 2003). When a public variety is created this reduces the demand for private varieties. The private sector responds by reducing the research effort.

\section{Summary \& Conclusion}

Based on our review of the evidence regarding plant research, especially as it relates to canola in Canada, the policies and programs that have merit as appropriate government tools to improve social wellbeing are the following: the public provision of basic research; targeted government subsidies (e.g., subsidies on the cost of R\&D or research output); charging fees above marginal cost to access basic research (or granting exclusive licenses); breeding varieties with indirect gains through health traits or environmental benefits; and investing in areas where industry may not invest (e.g., agronomic research, open pollinated non-HT varieties) or areas where IP are not present or well defined. 
Is there a role for government in today's agricultural research? - The answer is yes. Regarding applied research, governments should cooperate with private firms by providing research incentives and not competing with them. Regarding basic research, where property rights are still poorly defined; there may be an important role in the direct public provision of basic and applied research. Appropriate government policies and programs could contribute to sustainable development, growth and increased social wellbeing.

There have been significant benefits associated with the new canola varieties and traits developed through biotechnology. Producers benefit significantly from growing these new canola varieties and using these traits. Over time, yield gains and herbicide cost savings have led to very high gains to farmers from the adoption of HT canola seeding systems. The area seeded to canola varieties; the number of varieties available; and canola (especially hybrid) yields have increased dramatically. There are also important environmental benefits associated with new canola varieties and new technologies (e.g., better weed control; reduced tillage) \& significant health benefits (healthcare savings related to canola oils with health traits). Overall, there is substantial evidence of large, society wide, gains from the introduction of improved IPRs in Canada's canola sector.

\section{References}

Agriculture Financial Services Corporation (AFSC) (Various years) Yield Alberta: A planning tool for Alberta farmers. Lacombe, AB, Canada: Author.

Alberta Seed Guide (ASG) (Various years) Lacombe: Alberta Seed industry Partnership. DOI: http://www.seed.ab.ca/index.html.

Alston JM, Marra MC, Pardey PG, Wyatt TJ (1998) Research Returns Redux: A Metaanalysis of The Returns to Agricultural R\&D. EPTD Discussion Paper No. 38, pp. 44.

Brewin DG, Malla S (2012) The Consequences of biotechnology: a broad view of the changes in the Canadian canola sector, 1969 to 2012. AgBioForum 15(3): 257-275.

Brewin DG, Malla S (2014) Canola. In SJ Smyth, PWB Phillips, D Castle (eds). Handbook on Agriculture, Biotechnology, 621-641. Northampton: Edward Elgar.

Brinkman GL (2004) Strategic policy issues for agricultural research in Canada. Current Agriculture, Food and Resource Issues Canadian Agricultural Economics Society 5: 131-147.

Carew R (2000) Intellectual property rights: Implications for the canola sector and publicly funded Research1. Canadian Journal of Agricultural Economics/Revue Canadienne d'Agroeconomie 48 (2): 175-94.

European Academies Science Advisory Council (EASAC) (2013) Planting the Future: Opportunities and Challenges for Using Crop Genetic Improvement Technologies for Sustainable Agriculture. EASAC policy report 21. June 2013. Available at: www.ea sac.eu.

German Seed Alliance (n.d.) Oilseed Rape. DOI: http://www.german-seed-alliance.de/en/ produkte/raps/.

Gray R, Malla S (2001) In The biotechnology revolution in global agriculture: Innovation, invention, and investment in the canola industry. Vol. 24. Wallingford edited by Phillips, P.W.B. and G.G. Khachatourians, UK: CABI Pub. 
Gray R, Malla S (2007) The Rate of Return to Agricultural Research in Canada. Canadian Agricultural Innovation Research Network (CAIRN) Policy Briefs, Saskatoon, SK. 2007: 11 .

Gray R, Malla S, Phillips PWB (2001) Industrial development and collective action. In PWB Phillips, GG Khachatourians (eds) The Biotechnology Revolution in Global Agriculture: Innovation, Invention and Investment in the Canola Industry. Wallingford, Oxon, UK: CABI Publishing.

Gray R, Malla S, Phillips PWB (2006) Product innovation in the Canadian Canola sector. Supply Chain Management: An International Journal 11 (1): 65-74.

Gusta M, Smyth SJ, Belcher K, Phillips PWB, Castle D (2011) Economic benefits of genetically-modified herbicide-tolerant canola for producers. AgBioForum 14(1): 113.

Huffman WE, Evenson RE (1993) Science for Agriculture: A Long-Term Perspective. Ames, IA: Iowa State University Press.

Klumper W, Qaim M (2014) A Meta-Analysis of the Impacts of Genetically Modified Crops. PLoS ONE 9(11): e111629. Retrieved from https://doi.org/10.1371/journal. pone.0111629. [Accessed 10 April 2017].

Malla S, Hobbs JE, Perger O (2007) Valuing the health benefits of a novel functional food. Canadian Journal of Agricultural Economics 55(1): 115-136.

Malla S, Brewin DG (2015) The value of a new biotechnology considering R\&D investment and regulatory issues. AgBioForum 18(1): 6-25.

Malla S, Brewin DG (2019) Crop research, biotech canola, and innovation policy in Canada: Challenges, opportunities and evolution. Canadian Journal of Agricultural Economics 67(2): 135-150.

Malla S, Gray R (2003) Public research policy for today's agricultural biotech research industry. Canadian Journal of Agricultural Economics 51(2003): 347-369.

Malla S, Gray R (2005) The crowding effects of basic and applied research: a theoretical and empirical analysis of an agricultural biotech industry. American Journal of Agricultural Economics 87(2): 423-438.

Malla S, Gray R, Phillips P (2004) Gains to research in the presence of intellectual property rights and research subsidies. Review of Agricultural Economics 26(1): 6181.

Manitoba Agricultural Services Corporation (n.d.) Manitoba Management Plus Program: MMPP variety yield data browser [database]. Portage la Prairie, MB, Canada.

Manitoba Agriculture, Food and Rural Development (2011) Guidelines for estimating crop production costs-2011. Manitoba: Author.

Nagy JG, Furtan WF (1978) Economic costs and returns from crop development research: the case of rapeseed breeding in Canada. Canadian Journal of Agricultural Economics 26(1): 1-14.

Phillips PWB (2003) The economic impact of herbicide tolerant canola in Canada. In N Kalaitzandonakes (ed) The Economic And Environmental Impacts Of Agbiotech: A Global Perspective, 119-140. New York: Kluwer Academic Publishers.

Saskatchewan Crop Insurance Corporation (SCIC) (2017) Canola Provincial Average Yields by VARIETY. Available at: https://bit.ly/2l3pTDT.

Saskatchewan Ministry of Agriculture (2012) Crop Planning Guide 2011: Dark Brown Soil Zone. Saskatoon, SK: Author. Available at: https://bit.ly/2mkVYac.

SaskSeed Guide (Various years) Saskatoon, SK: Saskatchewan Seed Growers Association. Available at: http://www.saskseed.ca/guides.html.

Seed Manitoba (Various years) Winnipeg: Manitoba Agriculture, Food and Rural Development and the Manitoba Seed Growers' Association. Available at: http:// www.seedmb.ca/. 
Smyth SJ, Gusta M, Belcher K, Phillips PWB, Castle D (2010) Assessing the Economic and Ecological Impacts of Herbicide Tolerant Canola in Western Canada. Winnipeg: Canola Council of Canada. Retrieved from http://www.canolacouncil. org/media/50 4427/assessing_the_economic_and_ecological_impacts_of_herbicide _tolerant_canola_in_western_canada.pdf. [Accessed 10 May 2015].

Smyth SJ, Gusta M, Belcher K, Phillips PWB, Castle D (2011a) Changes in Herbicide Use After Adoption of HR Canola in Western Canada. Weed Technology 25(3): 492500.

Smyth SJ, Gusta M, Belcher K, Phillips PWB, Castle D (2011b) Environmental impacts from herbicide tolerant canola production in Western Canada. Agricultural Systems 104(5): 403-10.

Statistics Canada. (n.d.). CANSIM table 32100359: Estimated areas, yield, production, average farm price and total farm value of principal field crops, in metric and imperial units, annually [database]. Ottawa: Government of Canada.

Ulrich A, Furtan WH (1985) An Investigation in the Rates of Returns from the Canadian Crop Breeding Program. Unpublished report, Department of Agricultural Economics, University of Saskatchewan, Saskatoon, SK.

Ulrich A, Furtan WH, Downey K (1984) Biotechnology and Rapeseed Breeding: Some Economic Considerations. Ottawa, ON: Science Council of Canada. 
